\title{
Announcing the Congressional Fellowship Program, 1989-90
}

The American Political Science Association Invites Applications for the 37th CFP Competition

Political Scientists: Opportunities for young and mid-career political scientists to learn more about the legislative process by working as congressional aides for nine months.

Qualifications: Scholarly interest in Congress and the policy process and a Ph.D. completed within the last fifteen years (or near completion). Stipend: $\$ 20,000$, plus travel allowance. The stipend may be supplemented, at the fellow's initiative, with university support.

Fellowship Year: Orientation begins in November 1989; office assignments run from December 1989 through August 15, 1990.
Applications: Application materials must be submitted prior to December 1, 1988. Awards will be announced by March 15, 1989. Submit SIX COPIES of:

- A detailed curriclum vitae;

- A personal statement of about 500 words explaining how the Congressional Fellowship Program relates to your professional career goals;

- A sample of your best professional writing (one published or unpublished manuscript or paper).

In addition, applicants should submit the names of three professional references who will send letters of recommendation to our office by December 15, 1988. (Applicant is responsible for seeing that letters are sent.)

All materials should be mailed to: Director, Congressional Fellowship Program, American Political Science Association, $1527 \mathrm{New}$ Hampshire Avenue, N.W., Washington, D.C. 20036.

\section{The}

Political Science

\section{Teacher}

\section{Microform Copy of The Political Science Teacher}

The American Political Science Association announces a new service for the readers of The Political Science Teacher. In cooperation with University Microfilms International, TPST is now available on microform, which includes $105 \mathrm{~mm}$ microfiche and $16 \mathrm{~mm}$ and $35 \mathrm{~mm}$ microfilm. In addition, UMI offers copies of TPST-from individual articles to entire issues. For further information contact:

University Microfilms International

300 North Zeeb Road

Ann Arbor, MI 48106-1346

(313) $761-4700$

\section{American}

Political Science

Association

I 527 New Hampshire Ave., N.W. Washington, D.C. 20036

(202) 483-2512 